J. Clin. Chem. Clin. Biochem.

Vol. 25, 1987, pp. 889-892

(C) 1987 Walter de Gruyter \& Co. Berlin - New York

\title{
Evaluation of an Immunoturbidimetric Microalbuminuria Assay
}

\author{
By Lea Paloheimo, M. Pajari-Backas, E. Pitkänen
}

United Laboratories Ltd, Helsinki, Finland

L. Melamies and R. Rissanen

Orion Diagnostica, Research and Development Department, Espoo, Finland

(Received April 6/September 7, 1987)

\begin{abstract}
Summary: We have evaluated an immunoturbidimetric method for the estimation of urinary albumin. The method, besides being easy to perform and cost-effective, was sensitive enough to detect an even slightly increased albumin excretion (detection limit $5 \mathrm{mg} / \mathrm{l}$ ). Within-rùn reproducibility was 1.8 and $2.1 \%$, and between-run reproducibility 2.9 and $4.3 \%$ in samples containing $16.1-17.8 \mathrm{mg} / 1$ and $50.6-54.0 \mathrm{mg} / 1$ of albumin, respectively. The recovery of albumin added to the samples was $98.6-106.6 \%$. Results obtained by this method correlated well with the results obtained by radial immunodiffusion $(r=0.980, n=44)$ and radioimmunoassay $(r=0.982, n=41)$. The immunoturbidimetric method can be easily adapted for several clinical chemistry analysers.
\end{abstract}

\section{Introduction}

Diabetic nephropathy is a serious late complication in patients with Type 1 (insulin-dependent) diabetes mellitus. Prospective studies have indicated that patients with microalbuminuria have an especially high risk of developing clinical nephropathy (1) and that constant microalbuminuria can be used as a predictor of nephropathy $(1,2,3)$. Microalbuminuria may regress $(4,5)$ by intensification of insulin treatment, suggesting that the development of clinical nephropathy can be postponed or avoided in these patients.

The determination of microalbuminuria has become an important test for screening incipient nephropathy in diabetics and in clinical follow-up studies. Hospital testing for microalbuminuria is increasing rapidly, and there is a need for a rapid and inexpensive method which would be sensitive enough to measure minute amounts of urinary albumin. Various techniques, including radioimmunological $(2,6)$, enzyme immunological (7), immunonephelometric (8), immunoturbidimetric $(9,10,11)$ and radial immunodiffusion methods $(12,13)$ have been introduced, but so far it is not yet clear which one of the alternatives should be preferred. Immunoturbidimetry is a simple and rapid technique, in which the turbidity can be measured with photometers which are common in clinical laboratories, and the method is sensitive enough for clinical purposes (11). In the present study we compare a new sensitive immunoturbidimetric method with a radioimmunological method and with a method based on radial immunodiffusion.

\section{Materials and Methods \\ Urine samples}

24 hour urine samples were collected from 44 patients and 27 healthy volunteers. Samples were centrifuged and stored at $+4^{\circ} \mathrm{C}$, with thymol crystal added as preservative.

\section{Reagents}

Antiserum (porcine anti-human-albumin serum), Reaction Buffer, containing $5 \%$ polyethylene glycol 6000 , and Human Protein Reference Serum were all from Orion Diagnostica, Espoo, Finland. Albustix ${ }^{\star}$ was from Ames Division, Miles Laboratories Limited, Stoge Poges, Slough SL2 4LY, England. Pharmacia Albumin RIA-kit was a kind gift from Pharmacia AB, Uppsala, Sweden. 


\section{Radioimmunoassay}

The radioimmunoassay (RIA) was performed using ${ }^{125}$ I-labeled albumin and the double antibody technique as recommended by the manufacturer. The activity of the samples was measured with a NE 1612 Gamma Counter (Nuclear Enterprises LTD, Sighthill, Edinburgh, U.K.) with an efficiency of 70 per cent.

\section{Radial immunodiffusion}

Radial immunodiffusion (RID) was performed according to Mancini (12).

\section{Immunoturbidimetry}

Immunoturbidimetric assays were carried out with a Multistat ${ }^{(B)}$ III F/LS Micro Centrifugal Analyser (Instrumentation Laboratory, Ltd, Warrington, Cheshire, U. K.) and a FP-9 Clinical Chemistry Analyser (Labsystems, Helsinki, Finland).

Preparation of samples, references and antiserum reagent

Urine Specimens were centrifuged and then screened with Albustix ${ }^{\oplus}$. If the results were negative (albumin concentration below $300 \mathrm{mg} / \mathrm{l}$ ), the samples were used undiluted. If the results were positive they were prediluted with saline to correspond to the assay range. The Human Protein Reference Serum was diluted with saline to obtain an albumin concentration range from 5 to $100 \mathrm{mg} / \mathrm{l}$. Antiserum was diluted with Reaction Buffer 16-fold for the Multistat ${ }^{\text {(3) }}$ III and 2-fold for the FP-9.

\section{Assay procedures}

\section{Multistat ${ }^{\oplus}$ III}

The loader settings were: $40 \mu$ of sample were washed in with $20 \mu \mathrm{l}$ of water, and $180 \mu \mathrm{l}$ of antisera dilution were washed in with $10 \mu \mathrm{l}$ of water. Analyser settings were following:

$\begin{array}{lc}\text { Specific protein test tape } \\ \text { Wavelength } & 340 \mathrm{~nm} \\ \text { Temperature } & 30{ }^{\circ} \mathrm{C} \\ \text { Delay time } & 3 \mathrm{~s} \\ \text { First read interval } & 3 \\ \text { Data time } & 60 \mathrm{~s} \\ \text { Second read interval } & 5\end{array}$

Measuring time was 4 minutes. The results were calculated automatically in milligrams per liter.

FP-9

$350 \mu \mathrm{l}$ of Reaction Buffer and $100 \mu \mathrm{l}$ of urine sample or reference were pipetted into cuvettes, mixed and incubated for 5 minutes (blank). The reaction was started by adding $50 \mu$ l of antiserum dilution. Absorbances at $340 \mathrm{~nm}$ were read after 2 minutes. The results were calculated manually with the aid of a reference curve.

\section{Results}

\section{Reference curves}

Typical reference curves for albumin obtained by the immunoturbidimetric methods are shown in figure 1. A measuring range of $5-100 \mathrm{mg} / \mathrm{l}$ was selected for microalbuminuria determinations. Although the de-

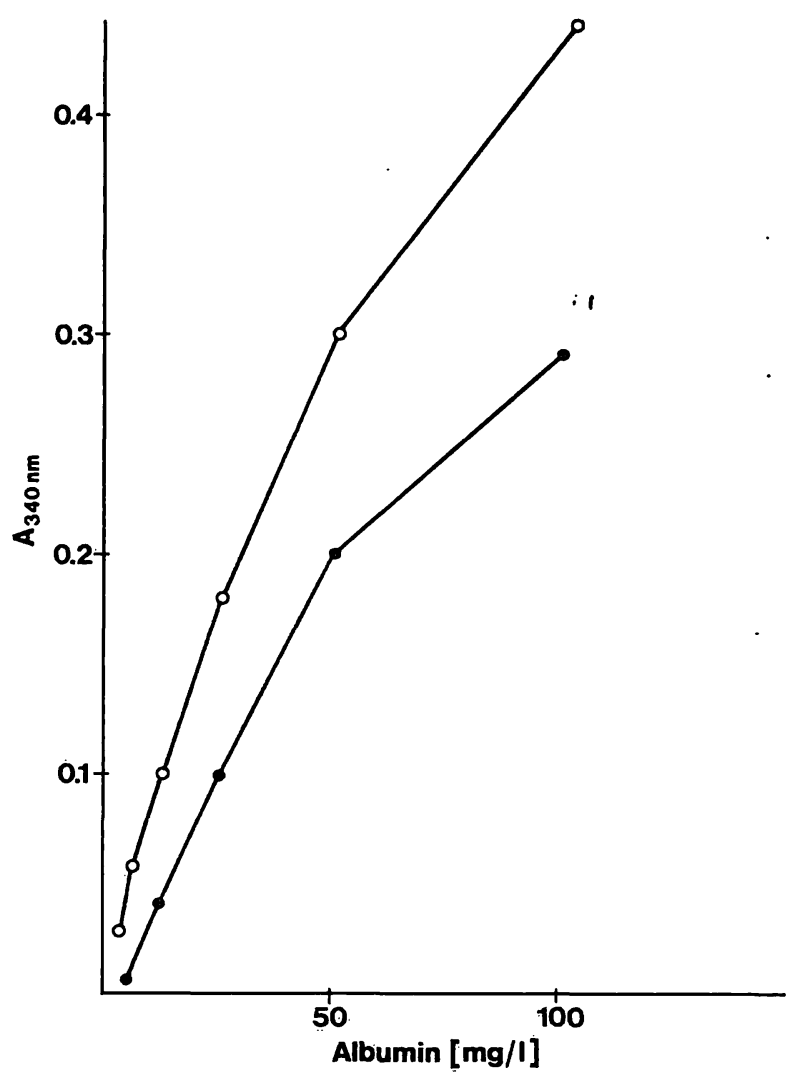

Fig. 1. Reference curves for the determination of albumin by immunoturbidimetry measured by the Multistat ${ }^{\circledR}$ III F/LS Micro Centrifugal Analyser and by the FP-9 Clinical Chemistry Analyser (O FP -9 and $\bullet$ Multistat ${ }^{\circledR}$ III).

tection limit is $5 \mathrm{mg} / \mathrm{l}$, it is sensitive enough to detect even slighty increased albumin excretion. The antigen excess was reached at concentrations above $400 \mathrm{mg} / 1$ as shown in figure 2 .

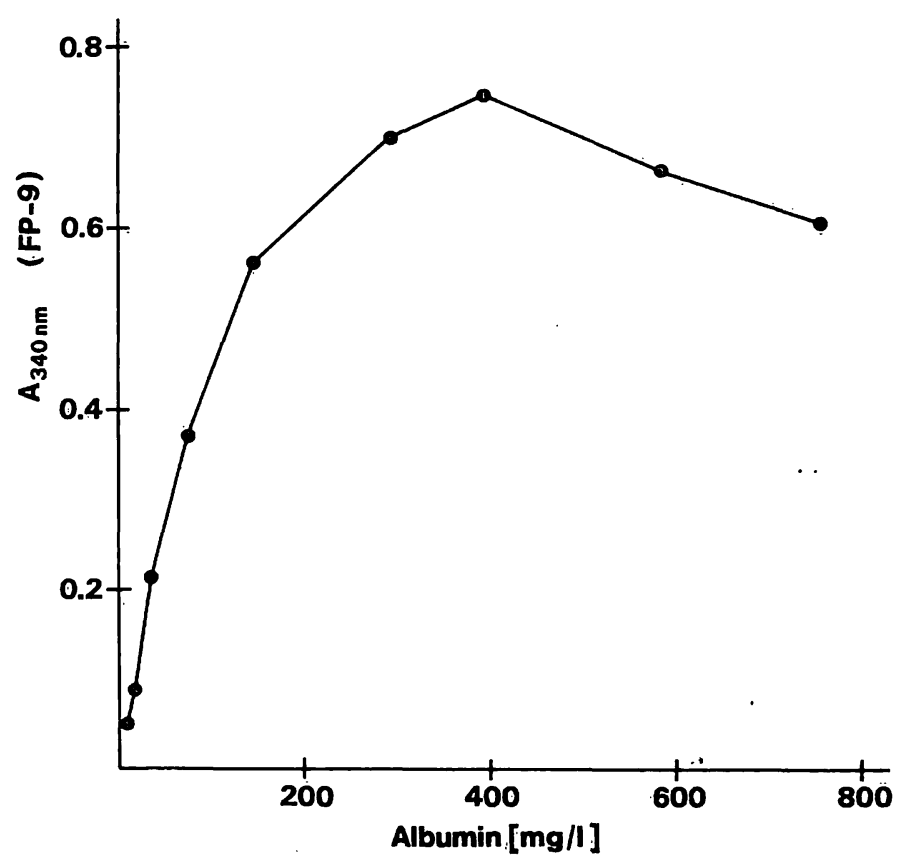

Fig. 2. Antigen excess curve of immunoturbidimetric urinary - albumin assay (FP-9). 


\section{Reproducibility}

Precision studies were performed by using two pools of urine with low and high albumin concentration. Within-run reproducibilities varied from 1.8 to $2.1 \%$, and between-run reproducibilities were from 2.9 to $4.3 \%$ (tab. 1 ).

\section{Correlations}

The immunoturbidimetric method on the Multistat III was compared with the radial immunodiffusion method, radioimmunoassay, and with another immunoturbidimetric method (FP-9). Data are shown in table $2(\mathrm{r}=0.980, \mathrm{r}=0.982$, and $\mathrm{r}=0.983$ for Multistat ${ }^{\circledR}$ III versus RID, RIA and FP-9, respectively). Figure 3 shows the correlation curve for Multistat $^{\circledR}$ III versus RID.

\section{Linearity}

The linearity of the method was tested by serially diluting pooled human urine of very high albumin concentration with saline (tab. 3).

\section{Analytical recovery}

Known amounts of albumin were added to a pooled urine specimen and assayed in duplicate. Albumin recovery varied from 98.0 to $106.6 \%$ (tab. 4).

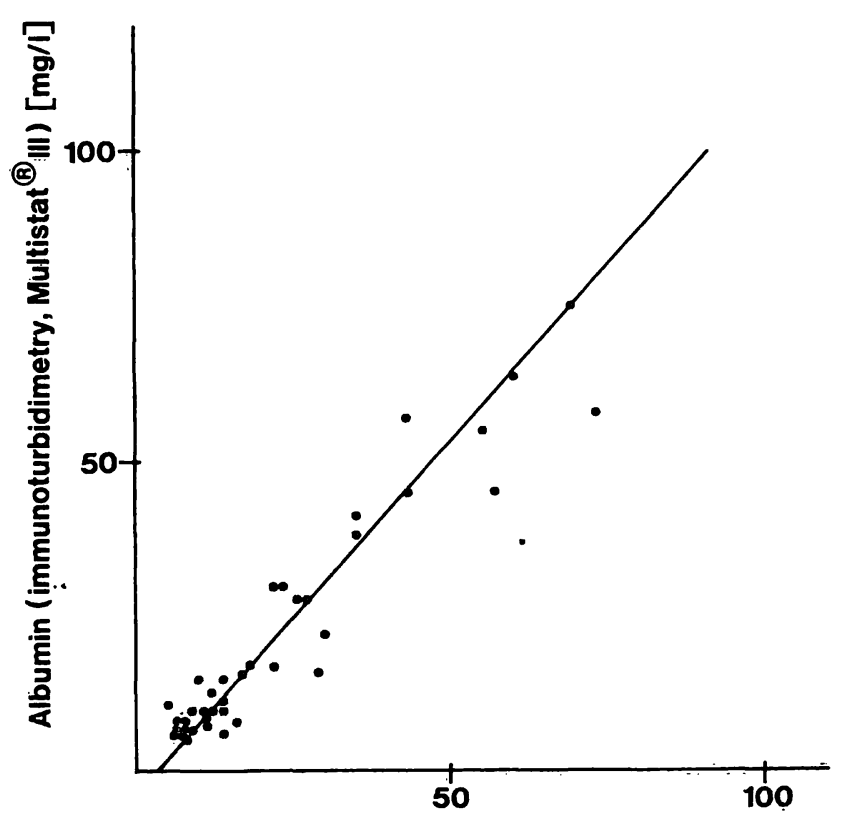

Albumin (radial immunodiffusion) [mg/ll]

Fig. 3. Correlation between immunoturbidimetry (Multistat ${ }^{\oplus}$ III) and radial immunodiffusion for albumin $(\mathrm{y}=1.15 \mathrm{x}-4.18, \mathrm{r}=0.980, \mathrm{n}=44)$.
Tab. 1. Reproducibility of immunoturbidimetric assay of urinary albumin using Multistat ${ }^{\circledR}$ III.

\begin{tabular}{lllll}
\hline & \multicolumn{4}{l}{ Albumin (mg/l) } \\
\cline { 2 - 5 } & Mean & SD & CV (\%) & $\mathrm{n}$ \\
\hline Within-run & 16.1 & 0.33 & 2.1 & 10 \\
Between-run & 50.6 & 0.90 & 1.8 & 12 \\
& 17.8 & 0.76 & 4.3 & 13 \\
& 54.0 & 1.57 & 2.9 & 20 \\
\hline
\end{tabular}

Tab. 2. Correlation of immunoturbidimetric urinary albumin assay (Multistat ${ }^{\circledR}$ III) with radial immunodiffusion, radioimmunoassay, and another immunoturbidimetric method (FP-9).

\begin{tabular}{llll}
\hline $\mathrm{y} / \mathrm{x}$ & $\mathrm{n}$ & $\mathrm{r}$ & Regression equation \\
\hline Multistat $^{\circledR}$ III /RID & 44 & 0.980 & $\mathrm{y}=1.15 \mathrm{x}-4.18$ \\
Multistat $^{\circledR}$ III/RIA & 41 & 0.982 & $\mathrm{y}=1.29 \mathrm{x}-3.34$ \\
Multistat $^{\circledR}$ III/FP-9 & 44 & 0.983 & $\mathrm{y}=0.90 \mathrm{x}-4.26$ \\
\hline
\end{tabular}

Tab. 3. Linarity of immunoturbidimetric assay for urinary albumin using Multistat ${ }^{\circledR}$ III.

\begin{tabular}{|c|c|c|c|c|c|}
\hline \multirow[t]{2}{*}{ Sample } & \multicolumn{5}{|c|}{ Albumin $(\mathrm{mg} / \mathrm{l})$} \\
\hline & $\begin{array}{l}\text { Dilution } \\
1 / 16\end{array}$ & $1 / 32$ & $1 / 64$ & $1 / 128$ & $1 / 256$ \\
\hline 1 & 1056 & 1140 & 1030 & 896 & - \\
\hline 2 & - & 2880 & 3266 & 3261 & 3098 \\
\hline 3 & 926 & 914 & 876 & 870 & - \\
\hline 4 & - & 2688 & 2802 & 2661 & 2685 \\
\hline 5 & - & 2304 & 2464 & 2367 & 2757 \\
\hline
\end{tabular}

Tab. 4. Analytical recovery of urinary albumin by immunoturbidimetric assay using Multistat ${ }^{\left({ }^{\circ}\right.}$ III.

\begin{tabular}{llc}
\hline Albumin (mg/l) & & \\
\hline Added & Recovered & Recovery (\%) \\
\hline 22.1 & 21.8 & 98.6 \\
34.8 & 35.2 & 101.1 \\
60.1 & 64.1 & 106.6 \\
\hline
\end{tabular}

\section{Normal values}

A daily urinary albumin excretion study was conducted with 27 healthy volunteers. 12 persons had urinary albumin concentrations below $5 \mathrm{mg} / \mathrm{l}$ and 15 persons from 5.4 to $15.9 \mathrm{mg} / \mathrm{l}$ (from 6.3 to $16.4 \mathrm{mg}$ / 24 hour). Three persons had a level above $10 \mathrm{mg} / \mathrm{l}$. These results agree well with earlier findings (8). 


\section{Stability of albumin in urine}

Samples were prepared by adding varying amounts of human serum albumin to a fresh urine sample. Samples were stored at $+4{ }^{\circ} \mathrm{C}$ and $-20^{\circ} \mathrm{C}$. Measurements were performed on freshly prepared samples and on samples stored for one week, one month and three months. the measuring range was extended to $160 \mathrm{mg} / \mathrm{l}$ of albumin. As shown in table 5 , the stability of albumin in urine was good when the samples were stored in a refrigerator and when they were frozen.

Tab. 5. Albumin stability in urine samples (FP-9). A normal urine sample with and without an excess of albumin was measured after storing one week, one month or three months either in a refrigerator or in a freezer.

\begin{tabular}{lrrrr}
\hline $\begin{array}{l}\text { Albumin } \\
\text { added } \\
(\mathrm{mg} / \mathrm{l})\end{array}$ & Beginning & 1 week & 1 month & 3 months \\
\hline$+4^{\circ} \mathrm{C}$ & & & & \\
0 & & & & \\
15 & 7 & 7 & 7 & 6 \\
50 & 23 & 22 & 22 & 21 \\
100 & 58 & 58 & 56 & 50 \\
200 & 108 & 115 & 103 & 92 \\
& $>160$ & $>160$ & $>160$ & $>160$ \\
0 & & & & \\
0 & & 7 & 6 & 6 \\
15 & & 22 & 21 & 20 \\
50 & & 56 & 57 & 52 \\
100 & & 112 & 101 & 96 \\
200 & & $>160$ & $>160$ & $>160$ \\
\hline
\end{tabular}

\section{Discussion}

Radioimmunoassay is the method originally used (6) in the detection of microalbuminuria. The method is very sensitive, but has pitfalls common to all radioimmunological methods. It is rather costly, relatively slow, and the radioactive reagent deteriorates rapidly. In addition, it involves precautions in handling of radioactive material and special measuring equipment.

\section{References}

1. Viberti, G. C., Hill, R. D., Jarret, R. J., Argyropoulos, A., Mahmud, U. \& Keen, H. (1982) Lancet $I, 1430-1432$.

2. Mogensen, C. E. \& Christensen, C. K. (1984) N. Engl. J. Med. 311, 89-93.

3. Mogensen, C. E. (1984) N. Engl. J. Med. 310, 356-360.

4. The Kroc collaborative study group (1984) N. Engl. J. Med. $311,365-372$.

5. Viberti, G. C., Pickup, J. C., Jarret, R. J. \& Keen, H. (1979) N. Engl. J. Med. 300, 638-641.

6. Keen, H. \& Chlouverakis, C. (1963) Lancet $I I, 913-914$.

7. Mohamed, A., Wilkin, T., Leatherdale, B. \& Davies, R. (1984) J. Immunol. Methods 74, 17-22.

8. Harmoinen, A., Ala-Houhala, I. \& Vuorinen, P. (1985) Clin. Chim. Acta 149, 269-274.
Radial immunodiffusion, another method measuring urinary albumin excretion, is cheaper but the prolonged incubating time makes the method rather impractical. Also, the immunoreaction may be rather difficult to read at low albumin concentrations, which makes quantification inaccurate.

In contrast, the immunoturbidimetric method is cheap, rapid and suitable for serial analysis. No special equipment is needed and this method can easily be adapted for several clinical chemistry analysers.

The albumin concentrations obtained by the immunoturbidimetric method (Multistat ${ }^{\circledR}$ III) correlated closely with the values obtained by the radioiminunoassay and by the radial immunodiffusion method (tab. 2), and also with another immunoturbidimetric method (FP-9). The measuring range of $5-100 \mathrm{mg} / 1$ is suitable for discriminating the samples with normal albumin concentrations from those with slightly ele= vated values. The method was highly reproducible even at the high normal urinary albumin concentration $(\overline{\mathrm{x}}=16.1 \mathrm{mg} / \mathrm{l}, \mathrm{CV}=2.1 \%, \mathrm{n}=10)$.

The rather high limit of antigen excess $(400 \mathrm{mg} / \mathrm{l})$ allows the determination of all Albustix ${ }^{\circledR}$-negative samples (albumin concentration below $300 \mathrm{mg} / \mathrm{l}$ ) without prior dilution of the sample. Albustix ${ }^{\circledR}$-negative samples with albumin concentrations higher than 100 $\mathrm{mg} / \mathrm{l}$ should then be diluted 4-fold and the test should be repeated within the optimal measuring range (fig. 1). Albustix ${ }^{\circledR}$-positive samples can be measured with appropriate dilution of the samples prior to analysis. In this way the number of off-scale samples is minimised. The immunoturbidimetric method should be especially suitable for use in the out-patient department and during duty activity where a rapid and simple method is needed.

\section{Acknowledgement}

We thank Helena Halme for providing the urine specimens and Manu Munter for valuable discussions.

9. Teppo, A.-M. (1982) Clin. Chem. 28, 1359-1361.

10. Spencer, K. \& Price, C. P. (1979) Clin. Chim. Acta 95, $263-276$.

11. Rowe, D. J. F., Hayward, M., Bagga, H. \& Betts, P. (1984) Br. Med. J. 289, 957-959.

12. Parving, H. H., Oxenboll, B., Svendsen, P. A. A. \& Sandahl Christiansen, J. (1982) Acta Endocrinol. 100, 550-555.

13. Barnett, A. H., Dallinger, K., Jennings, P., Fletcher, J. \& Odugbesan, O. (1985) Lancet $I, 53-54$.

Lea I. Paloheimo

United Laboratories Ltd.

P. O. Box 70

SF-00511 Helsinki 